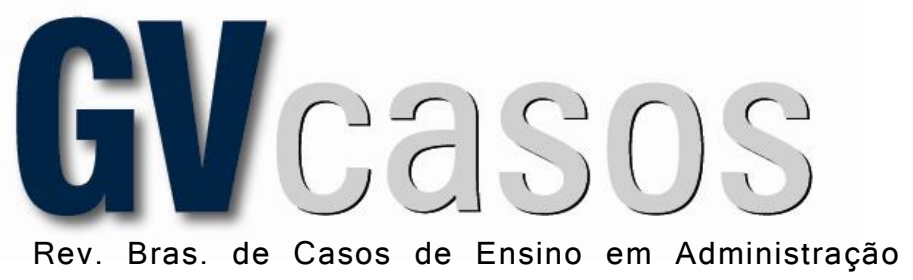

DOI: http://dx.doi.org/10.12660/gvcasosv4n2c16

\title{
THE EXPANSION OF COMMUNITY BANKS IN BRAZIL: DISCOVERING PALMAS' METHODOLOGY
}

MARLei Pozzebon - marlei.pozzebon@ hec.ca

HEC Montréal - Montreal, Canadá

Tania Pereira Christopoulos ${ }^{1}$ - tchristo@ osite.com.br

Escola de Artes, Ciências de Humanidades da Universidade de São Paulo - São Paulo, SP, Brasil

JAHAN ARA PeERALy - jahan.peerally@ hec.ca

HEC Montréal - Montreal, Canadá

Fabio Prado Saldanha - fsaldanha@ hec.ca

HEC Montréal - Montreal, Canadá

Submissão: 06/01/2014 | Aprovação: 21/08/2014

\begin{abstract}
It has been 14 years since Banco Palmas was created. Joaquim Melo, its coordinator, feels that it is time to reconsider some of the fundamental premises upon which this community bank was built. The case provides an overview of the importance of a holistic view of financial inclusion to promote local development. It is indicated to discuss social inclusion and local development.
\end{abstract}

Keywords: Social inclusion, Bank, Technology, Development, Estrategy.

"During 30 years, we have grown by encompassing the most deprived neighbourhoods of Fortaleza to form the large Conjunto Palmeiras. As a result, we contributed to reducing the poverty of many people. Our community is an example of income distribution. Our inhabitants do not have the same income as many others living in richer parts of Fortaleza, but they have at least a minimum yield, they are motivated and they feel like citizens. We have also created a huge network of community banks in Brazil and we are serving as an example for many other developing countries. This is a very different reality from 1973, when the community was a slum, in the middle of a swamp. We recognize the valuable accomplishment but we need to reflect: fourteen years ago, when we created Banco Palmas, we wished to avoid the diversion of resources from Conjunto Palmeiras to other localities in order to reduce impoverishment. Now, we have another challenge: we need to find ways to bring in resources from outside and, at the same time, to keep our people motivated to generate wealth inside the community."

After proffering these words at an international conference, where he reflected on the Banco Palmas model, its founder, Joaquim de Mello, is glad to return to Brazil and see the face of his trusted right-hand man, Asier Ansonera, waiting for him at the international airport. As they start their car ride to Conjunto Palmeiras, where Banco Palmas is headquartered, Joaquim says to Asier:

\footnotetext{
${ }^{1}$ Na elaboração deste trabalho, a autora Tania Pereira Christopoulos contou com bolsa CNPq.
} 
THE EXPANSION OF COMMUNITY BANKS IN BRAZIL: DISCOVERING PALMAS’ METHODOLOGY Marlei Pozzebon, Tania Pereira Christopoulos, Jahan Ara Peeraly, Fabio Prado Saldanha

"It has been 28 years since I first arrived in Conjunto Palmeiras and 14 years since Banco Palmas was created. Our community bank is unique in that it is the first of its kind and it is a model which several countries and regions wish to emulate. I have discussedwith authorities from Brazil and other countries interested in emulating the Banco Palmas model - possible ways to anticipate the challenges which may come after the model has served its first purpose: to bring initial development to those involved in it. I feel that it is time to reconsider some of the fundamental premises upon which Banco Palmas had been built, at least in Conjunto Palmeiras, since the bank's true purpose in our beloved community has been fulfilled".

Seeing that Joaquim looked tired from his long flight, Asier decided to let him rest during the drive, as they both silently reflected on the history of Banco Palmas's emergence and the recent creation of almost a hundred new community banks, all inspired by its basic model.

\section{From seaside to swamp to Conjunto Palmeiras}

Fortaleza, the capital of the Northeast state called Ceará, has a population of 2.5 million inhabitants and is a major tourist destination attracting around 2 million visitors per year to its whitesand beaches, blue-water ocean, warm temperatures and exciting nightlife.

Today, one can observe a modern tourist infrastructure threading the city's coastal and wealthiest area (Appendix 1). However, this area of Fortaleza has not always been a haven for tourists and the wealthy. In fact, prior to 1973, this coastal region of the city was occupied by fishermen and low-income families (Appendix 2).

Seeing the potential for tourism growth, coupled with the appreciation of real estate in the area, the local municipality implemented an urbanization policy which involved driving all those fishermen and low-income families, the so-called favelados (a derogatory term for slum residents, favela meaning slum), out of the area. This urban policy, executed by the Fortaleza Social Service Foundation, involved displacing slum residents from the central, privileged districts of Fortaleza, to suburban and undeveloped areas of the city.

The displaced residents were forced to abandon their homes by the seaside while they were granted a vast stretch of land in a swampy and empty area located on the outskirts of Fortaleza, about 22 kilometers away from the ocean. While the city was focused on developing tourism, its urban policy, on the other hand, neglected to deal with existent structural and social problems such as the displacement imposed on the slum residents. The swampy land allocated to the displaced residents was far from schools and city jobs and devoid of basic urban facilities such as public transportation, water supply, sanitation and electricity. It was, therefore, in these dismal conditions that the community of displaced 1,500 low-income families, called Conjunto Palmeiras (loosely translated as the Neighbourhood of Palm Trees, the latter being indigenous to the area), was born in 1973.

From 1973 to 1981, the population of Conjunto Palmeiras grew significantly due to additional settlement by migrants coming from Brazil's interior rural areas. Within a short period of time, Conjunto Palmeiras expanded into a peri-urban slum of 32,000 inhabitants. As in the case of other Brazilian favelas, this expansion took place in the absence of basic infrastructures and social services. The inhabitants lived in dreadful conditions with very low levels of, and possibilities for, human development.

\section{The birth of a neighborhood association}

After years of subsisting under an authoritarian regime, the early 1980s saw a period of gradual re-democratization of Brazil's society. Civil associations and community activist movements, which had hitherto been banished or inhibited, flourished vigorously. In this wave of change, in 1981 the residents of Conjunto Palmeiras, who were still largely neglected by the municipal government, created a neighbourhood association called Associação dos Moradores do Conjunto Palmeiras (ASMOCONP, Residents Association of Conjunto Palmeiras; see Appendix 3). Headed by local 
THE EXPANSION OF COMMUNITY BANKS IN BRAZIL: DISCOVERING PALMAS' METHODOLOGY Marlei Pozzebon, Tania Pereira Christopoulos, Jahan Ara Peeraly, Fabio Prado Saldanha

community leaders and supported by progressive sectors of the Catholic Church and local/international NGOs, ASMOCONP's purpose was to help the community attain their rights to basic infrastructures such as access to water, electricity and education.

The results achieved by ASMOCONP's organized actions were noteworthy, though not immediate. It took seven years for the neighborhood to gain access to public water supply, an achievement still considered as one of the most difficult in the history of this community. Over these seven years, and through lobbying local authorities, ASMOCOMP brought outdoor lighting to neighborhood streets and electricity to the community's houses. Asphalt and sanitation, however, did not arrive until the 1990s, and was achieved through international aid. A partnership between ASMOCONP and GTZ, a German government-owned corporation specialized in sustainable development projects, provided funds and technical assistance for the construction of a sewage system and other urban improvements such as sidewalks and a drainage system. By the end of the 1990s, and as a result of nearly two decades of continuous effort, the former favela was finally urbanized.

Despite these urban improvements, rather than improving simultaneously, the socioeconomic condition of the community deteriorated to critical levels. In 1997, an informal census carried out by ASMOCONP revealed that most of the neighborhood's residents were unemployed or held precarious jobs. Ninety percent of the families lived on less than two minimum wages per month at the time when the minimum wage was $\mathrm{R} \$ 120$ per month, and the exchange rate was around $\mathrm{R} \$ 1.10$ per US dollar, meaning that $90 \%$ of families lived on less than approximately $\$ 109$ US a month, or \$4 US a day). Seventy-five percent of the adult population was illiterate, and at least 1,200 children of school age were not in school. Facing these living conditions, they could not afford the public fees for the new urban infrastructures like electricity and water. As a result, several families were compelled to put their houses on the market and leave the community. It was an ironic situation, since the burden of paying for these infrastructural improvements was driving out the neighborhood's residents. When asked: "Why are we poor?" all residents would respond: "Because we have no money!"2

\section{The leadership of Joaquim de Melo}

During the 1980s and 1990s, one of the community leaders and managers of ASMOCOMP, Joaquim de Melo (shown in Appendix 4), had a prominent and active participation in the struggles for bringing basic infrastructures and urbanization to the neighborhood.

Like the majority of Conjunto Palmeiras' households, Joaquim Melo had had a very poor childhood, growing up in a housing project in the city of Belém (state of Pará). In 1978, he joined the parish seminary in the hope of becoming a priest. However, six years later, he grew dissatisfied with his seminary life and it was at this junction that the archbishop of Fortaleza - Cardinal Aloisio Lorscheider - invited him and other seminary students to move to favelas and help the poor. Joaquim accepted the invitation and moved to the Rampa do Janguruçu - the garbage dump of the city of Fortaleza. During his five months at the Janguruçu, he was moved by the appalling living conditions of the garbage pickers. It was then that he decided to become an activist and uphold social causes ${ }^{3}$.

Following his assignment at Janguruçu, in 1984 he was requested by the archbishop to help Conjunto Palmeiras. It was also in this period that the life trajectory of Joaquim evolved away from the Church, and he left the priesthood in 1989 to devote himself to community projects. At that time, he had already won much respect in the community for the struggles he had undertaken to demand rights for the people of Conjunto Palmeiras. After nearly two decades working to secure advances in the community, Joaquim was concerned that the residents were beginning to leave Conjunto Palmeiras in 1997.

\footnotetext{
${ }^{2}$ http://www.inovacaoparainclusao.com/instituto-palmas.html

${ }^{3}$ https://www.ashoka.org/fellow/joaquim-de-melo-neto-segundo
} 
THE EXPANSION OF COMMUNITY BANKS IN BRAZIL: DISCOVERING PALMAS' METHODOLOGY Marlei Pozzebon, Tania Pereira Christopoulos, Jahan Ara Peeraly, Fabio Prado Saldanha

"This was happening to many families back then: the husband wasn't working, the kids were sick, the house was the family's only asset and they couldn't afford all those taxes, so the result was to sell the place and move away, since they couldn't sell husband and kids to keep the house"'(J.J.de Melo Neto Segundo, July 7, 2007).

Furthermore, local businesses and small producers were severely impeded by lack of access to credit and by difficulties in marketing their goods ${ }^{4}$. Thus, in that same year of 1997, ASMOCONP conducted another study on Conjunto Palmeiras residents' disposable income. The study revealed that the neighborhood's families spent an aggregate total of $\mathrm{R} \$ 1.2$ million per month - most of it outside Conjunto Palmeiras ${ }^{3}$. As Joaquim explained,

"We discovered one important thing: we remained poor not only because we had little money, but mostly because we were spending it outside the favela. An instrument had to be created for the community to both produce and consume locally" (Le Monde, May $26^{\text {th }} 2010$ ).

To break this cycle and pull the residents out of poverty, Joaquim and other colleagues jointly envisioned the creation of a first community bank in Brazil, the Banco Palmas.

Furthermore, local businesses and small producers were severely impeded by lack of access to credit and by difficulties in marketing their goods ${ }^{3}$.Thus, in that same year of 1997, ASMOCONP conducted another study on Conjunto Palmeiras residents' disposable income. The study revealed that the neighborhood's families spent an aggregate total of $\mathrm{R} \$ 1.2$ million per month - most of it outside Conjunto Palmeiras ${ }^{3}$. As Joaquim explained,

"We discovered one important thing: we remained poor not only because we had little money, but mostly because we were spending it outside the favela. An instrument had to be created for the community to both produce and consume locally" (Le Monde, May $26^{\text {th }} 2010$ ).

To break this cycle and pull the residents out of poverty, Joaquim and other colleagues jointly envisioned the creation of a first community bank in Brazil, the Banco Palmas.

\section{Banco Palmas, a bank that belongs to the community}

It was against this backdrop that ASMOCOMP redefined its priorities and created strategies for income generation. This shift in the association's priorities would inaugurate a new phase in Conjunto Palmeiras' history, where the Banco Palmas project would help the community rise from the ashes of socio-economic vulnerability.

Thus, Banco Palmas (see Appendix 5) was founded in January 1998 with an initial capital endowment of only 2,000 R \$ (Brazilian Reals), donated by a local NGO. Additional funds totaling $30,000 \mathrm{R} \$$ were obtained from other local and international NGOs during the first six months of operation and were earmarked for microcredit loans.

The two main objectives of this new phase in the association's strategy were to reduce financial exclusion in the community [even to this day $39 \%$ of Brazil's population do not have bank accounts, and a reported $41.2 \%$ of this population wishes to have one ${ }^{5}$ ] and to find ways to generate income through local development inside Conjunto Palmeiras.

In order to achieve the first objective, Banco Palmas was installed inside ASMOCOMP, allowing households to avoid traveling long distances to find a bank branch, and opening bank accounts for people unable to present the collateral usually required by traditional banks. The micro-

\footnotetext{
${ }^{4}$ França-Filho, G. C.; Silva-Júnior, J. T.; Rigo, A. S. (2012). Solidarity finance through community development banks as a strategy for reshaping local economies: lessons from Banco Palmas. Revista de Administração, São Paulo, 47 (3): 500-515.

${ }^{5}$ SCHIAVINATTO, F.; HOLANDA SCHMIDT, F.H. (2011). SIPS Bancos. Inclusão financeira e bancarização no Brasil. In Schiavinatto (org.). Sistema de indicadores de percepção social. Brasilia: IPEA. p181-210.
} 
THE EXPANSION OF COMMUNITY BANKS IN BRAZIL: DISCOVERING PALMAS’ METHODOLOGY Marlei Pozzebon, Tania Pereira Christopoulos, Jahan Ara Peeraly, Fabio Prado Saldanha

loans are provided by Banco Palmas decision, based on a specific methodology of credit evaluation which does not consult any formal credit protection data base. Residents apply for credit by filling out a form with their personal information, the loan value requested and the purpose for which the money is sought. After that, Banco Palmas' credit analyst visits the applicants' neighbors to gather more information about the lender. Being trustworthy and having a good reputation are two fundamental criteria for being approved.

Regarding the second objective, they developed instruments for promoting a production and consumption cycle within the community. As part of Banco Palmas' methodology, three instruments were designed to be used in combination with the microcredit issued by the bank. These three instruments include a social currency, a map of local production and consumption, and intensive professional training to trigger small business initiatives.

\section{Palma: a social currency}

In 2002, a local alternative currency - a social currency called Palma - was created by ASMOCOMP to encourage local consumption and, as a result, improve local commerce (see Appendix 6). At the time of its creation, the Palma was an unexpected novelty, leading to strong resistance from Brazilian authorities. It is reported that in 1998, when Banco Palmas was preparing to be launched, the police raided its then tiny office, following complaints from Brazil's Central Bank. Palmas' currency had not yet been printed, but the police seized a handwritten ledger and $1,000 \mathrm{R} \$$. Joaquim had to convince the government that the Palma was not a threat to the Real because it was pegged to the latter and as legitimate as a coupon (Wall Street Journal, Sept. 20 ${ }^{\text {th }} 2011$ ) used for bills and purchases payments. Hence, the Palma, which is printed on special paper with security coding to prevent forgery, is backed by the Real at one-to-one parity, so that for each Palma in circulation one Real is held in reserve by ASMOCOMP.

When obtaining a microcredit loan, specifically for consumption, the borrowers will receive Palma notes instead of $\mathrm{R} \$$ from Banco Palmas. As the Palma currency is only accepted within the boundaries of the neighbourhood, borrowers tend to spend the currency on local purchases. Converting the Palma into $\mathrm{R} \$$ is allowed only to registered merchants and can be done at any time at ASMOCOMP. This conversion is not permitted to consumers since the objective of the social currency is to improve local consumption ${ }^{6}$.

As mentioned earlier, one of the main objectives in creating a social local currency is to promote a production and consumption cycle within the community, so as to ensure that the multiplicative, income-generating effects of the microcredit loans remain in the local economy. To further ensure these positive effects, one line of microcredit is offered in the Palma currency in order to finance local consumers. To obtain the microcredit loan, the borrower does not have to present any documentation or formal guarantees like those required by formal credit institutions. Rather, the system is based simply on the borrower's local reputation, with neighbors giving assurance that the person applying for the loan is responsible and trustworthy. Additionally, loans issued in the social currency do not carry any interest. It is in those regards, that the Banco Palmas conditionality differs from those of traditional banks.

Another instrument created by Banco Palmas was the Palmacard (Appendix 7). It was launched in 1998, with the objective of providing immediate resources for essential items, and lasted around ten years. The Palmacard emulated a credit card, printed on a piece of paper and accepted only inside the community. When buying goods within the community, clients signed an invoice that was held by the merchant and cashed at Banco Palmas after one month. Palmacard was discontinued in 2008-2009, since it operated as a local handicraft and was not efficient - counting on the ability of the involved merchants to keep track of everything purchased in their stores and cashing the invoice

\footnotetext{
${ }^{6}$ http://www.institutobancopalmas.org/100-perguntas-mais-frequentes/
} 
THE EXPANSION OF COMMUNITY BANKS IN BRAZIL: DISCOVERING PALMAS’ METHODOLOGY Marlei Pozzebon, Tania Pereira Christopoulos, Jahan Ara Peeraly, Fabio Prado Saldanha

accordingly. However, this experience instigated interesting discussions about the importance of defining an economy based on collective human values.

In comparison to its precursors, Palmas social currency has survived many challenges and is still important inside Conjunto Palmeiras. Besides promoting the local production and consumption cycle, the use of Palmas also has the objective of building and reinforcing the community's political and social identity. The association Conjunto Palmeiras was developed through economic and social solidarity links among its inhabitants. Banco Palmas history follows this trend, having emerged in the wake of other solidarity economic initiatives inside the community. In this sense, the history of Palmas currency is part of a process of creating a solidarity economy. Even the iconographic creation of the currency is part of a collective process, in which the inhabitants take part.

Interestingly its circulation has recently started to decrease. According to Joaquim de Mello, three factors seem to contribute to this: most of the households are already used to making purchases inside the community with or without using Palmas; many credit cards are now accessible to low income inhabitants; and Banco Palmas do not promote the practice as before, since the objective of creating the habit of local consume has already been achieved ${ }^{7}$.

On the other hand, the social and political role of Palmas is still gaining focus. At the event of Copa das Confederações, in June 2013, Banco Palmas placed a kiosk at the International Airport of Fortaleza, where tourists could exchange dollars or any other currency for Palmas. The objective was to draw them to visit Conjunto Palmeiras and exchange Palmas for products. A special program with various activities, such as dance presentations, was created to introduce the community to those tourists in the course of the international soccer event. The community has promised to repeat the event in 2014 during the World Cup, and Joaquim is still working out agreements with a few big hotels so that they accept receiving the Palmas. The objectives go beyond strengthening and disseminating the Palmas: Joaquim wishes to attract the soccer tourists to the community and poor neighborhoods of Fortaleza so they can see the local culture.

These events appear to imply that Palmas is going to survive, even though in a different form. Recently, Banco Palmas engaged in a project to replace Palmas paper with an electronic currency. Under this new version it will be possible to make payments through mobile phones within Conjunto Palmeiras. For that, three different players will be involved: the mobile operator, credit card companies, and a traditional bank. This is an experimental project that has as a condition that all users have a bank account at the traditional bank, so that this bank can operationalize debits and credits for them. In order to adhere to the system, formal merchants should acquire a machine (POS) for $15 \mathrm{R} \$$ and pay the rate of $2 \%$ to a credit card operator (Redecard). Informal merchants should choose between receiving a machine from Redecard by paying a monthly rent of $15 \mathrm{R} \$$ or conducting operations through their own mobile, assuming they have access to the Internet.

The ideas to keep Palmas alive seem to be no end: at the beginning of 2012, Banco Palmas launched a pedagogical version of the currency: the Palminhas. That is a version for children, with bills of ten, twenty cents and one $\mathrm{R} \$$, so that they can buy candies (Appendix 8). This project was born from Joaquim's concern about adolescents growing up without having taken part in the process of Palmas creation. This generation is going to guide the future of Palmas, according to him!

\section{The production and consumption map, an innovative tool}

The second and leading characteristic of Banco Palmas' methodology is its annual "local consumption and production map" (Appendix 9), which is unique to Conjunto Palmeiras, thereby distinguishing it from all other Brazilian microcredit initiatives.

\footnotetext{
${ }^{7}$ MEYER, C., (2012). Les finances solidaires comme biens communs durables : étude de cas de la Banque communautaire de développement Palmas (Brésil). Dissertation présenté en vue de l'obtention du Master en sciences de la population et du développement. Université Libre de Bruxelles. Faculte des Sciences Sociales et Politiques
} 
THE EXPANSION OF COMMUNITY BANKS IN BRAZIL: DISCOVERING PALMAS' METHODOLOGY Marlei Pozzebon, Tania Pereira Christopoulos, Jahan Ara Peeraly, Fabio Prado Saldanha

The map is based on a detailed research operation implemented by Banco Palmas which provides up-to-date information on the quantity of products and services typically produced and consumed within the community. The information is collected through an extensive door-to-door survey carried out by young people from the community. The survey allows Banco Palmas to better evaluate which investments should be promoted or discouraged based on the local demand for particular products and services. The idea is to adjust the local supply to the local demand. By doing so, Banco Palmas is able to efficiently use its microcredit and professional training projects by specifically focusing on products and services which will satisfy the community's existing needs.

This mechanism allows the bank to finance local businesses based on both the needs and capacity of individual microentrepreneurs, while considering community development overall on a territorial basis. This also prevents individual micro-businesses from saturating the local market with a particular product or service and, thereby, causing existing competitors to collapse or be displaced.

This initiative is further supported by ASMOCOMP's promotion of a monthly local economic forum - FECOL (Appendix 10) - where micro-entrepreneurs and local residents meet and discuss the types of businesses to be promoted. The premise for the forum is that each community member, regardless of his/her educational level or economic situation, is an agent for bringing solutions to local problems. The neighborhood association, therefore, believes that sustainable and local development can only be achieved through a higher degree of self-management and thoughtful cooperation among residents and merchants.

The creation of a computing school in Conjunto Palmeiras exemplifies how investment is strategically directed towards the needs of the community, rather than to an individual entrepreneur. After it was determined that many young people in the community were spending hours travelling to more developed areas of the city in order to acquire computer knowledge and expertise necessary to gain access to better jobs, FECOL organizers decided that Banco Palmas should support the creation of a computer school within the neighborhood. Since there were no local entrepreneurs with experience in this domain, the bank convinced the owner of a small local market, who also had the largest building in Conjunto Palmeiras, to house the computing school business in his facility. Banco Palmas also believed that the market owner was the ideal, best equipped entrepreneur to expand into a totally new business activity. This is how the local market owner also became a successful computer school manager.

\section{Professional training to sustain productive microcredit loans}

Microcredit at Banco Palmas is a central piece of a larger array of activities aimed at enhancing local development. Thus, all the initiatives of Banco Palmas reflect a central philosophy based on the development of a "solidarity network" which integrates local producers and consumers in such a way that a large portion of the local wealth circulates locally, thereby maintaining the wealth in the community rather than generating income and employment elsewhere.

At the time when Banco Palmas was being created, professional qualification among community members was scarce. As a consequence, ASMOCOMP felt that a microcredit strategy in Conjunto Palmeiras would only be fruitful and sustainable if it was accompanied by complementary capacity-building actions. To address this lack of qualifications among local workers and producers, a variety of professional training courses and workshops have been offered by Banco Palmas since its inception. The aim is to provide members of the community with specific professional and business skills that will help them make fruitful use of the microcredit loans. Therein lies one of the most important premises of ASMOCOMP's developmental philosophy which is that: promoting financial support without engendering conditions that allow people to become true agents of their emancipation as citizens and entrepreneurs, is a recipe for failure.

Part of these capacity-building actions was accomplished by a number of empreendimentos solidários (solidarity businesses), which are small production units founded by ASMOCOMP and run as part of the Banco Palmas. The most important ones include Palma Fashion (small sewing 
THE EXPANSION OF COMMUNITY BANKS IN BRAZIL: DISCOVERING PALMAS' METHODOLOGY Marlei Pozzebon, Tania Pereira Christopoulos, Jahan Ara Peeraly, Fabio Prado Saldanha

factory), Palma Limpe (producing cleaning materials), Palma Natus (producing natural soaps) and Palm Arte (producing handicraft products). Each solidarity business (Appendix 11) is an independent and financially sustainable business operation. In the early years of activity when they were just starting up, they were all located within the association's building in order to reduce operating costs. Their purpose is to temporarily employ local workers and train them in specific professional and business skills, thereby enabling them to work thereafter for themselves or for other local businesses.

Another project, the Academia de Moda (Fashion Academy, Appendix 12) - taught by undergraduate and graduate students from two accredited fashion colleges in Fortaleza - is oriented towards young women, who are offered courses in sewing, tailoring, fashion design and marketing. Upon completing the courses, participants are eligible for microcredit loans from Banco Palmas to start their own sewing businesses.

The capacity-building actions are also complemented by a variety of training-oriented projects, sustained through partnerships with development agencies, NGOs and universities. One of these projects, the Bairro-Escola (Neighborhood School), is a training program aimed at community youths between 16 and 24 years of age. The program offers them the possibility of learning a new skill through a three-month internship in a local business, whether formal or informal in nature,. Both the trainees and the business owners receive small grants during the program, and in many cases the trainees are hired on a permanent basis after the internship. This project is funded by the Inter-American Foundation and was initiated in 2005 with the goal of training 1,000 youths in the first three years.

\section{The expansion of Banco Palmas in the 2000s}

In 2003, Banco Palmas created the Instituto Palmas (Palmas Institute) with the objective of replicating the bank's experiences throughout Brazil. As a result, in 2004, the second community bank, Banco Par, was opened in the nearby municipality of Paracuru. Two years later, five more community banks started their operations in other Brazilian states, thus leading to a network of Brazilian community banks. Instituto Palmas gradually developed procedures to ensure the proper functioning of the network and to validate the various community banks' policies, currencies and other attributes ${ }^{1}$.

Five years after the institute's creation, the community bank network escalated to 37 community banks, most of them in the state of Ceará, but some in the states of Bahia, Piauí and Paraíba. In 2009, this expansion reached the Southeast and the South of Brazil, with 12 new community development banks in the states of Minas Gerais, São Paulo and Rio Grande do Sul. In 2010, only two new community banks were joined in the network, one of them in the state of Rio de Janeiro. Nevertheless, in 2011 expansion advanced and reached 16 new community banks, with two new agencies in the state of Rio de Janeiro and penetration into the North of Brazil in the states of Amazonas and Acre. Eleven new community banks were opened in 2012, and in 2013, the number shot up to 103 banks (see Appendix 13). Spread across 19 Brazilian states, these banks provide excluded communities with access to banking services and products.

\section{From solo operations to partnerships}

In the beginning, it was a challenge for Instituto Palmas to manage the network's expansion due a lack of certain specific competencies and experience in the field. Moreover, an additional challenge was that Brazilian society in general was not familiar with the concept of a community bank. To overcome these challenges, Instituto Palmas developed partnerships with other financial institutions which had, for example, competencies in diagnosing demographic zones where community banks are needed and in providing support in start-up activities.

Among the first partnerships was the one created in 2005 between Instituto Palmas and Brazil's largest banking institution, Banco do Brasil, to develop a shared microcredit operation in Conjunto 
THE EXPANSION OF COMMUNITY BANKS IN BRAZIL: DISCOVERING PALMAS’ METHODOLOGY Marlei Pozzebon, Tania Pereira Christopoulos, Jahan Ara Peeraly, Fabio Prado Saldanha

Palmeiras. The partnership combined the strengths of each party. On the one hand, Banco do Brasil had extensive access to funds, as well as technological tools and back-office systems to support large-scale credit operations, but lacked knowledge of lending methodologies for microcredit clients. On the other hand, Instituto Palmas possessed expertise in microcredit practices and methodologies, but had limited access to funds and technology.

The partnership involved a progressive allocation of resources, starting from 50,000 R $\$$ in 2005. Since it was reimbursed by Instituto Palmas, Banco do Brasil provided 100,000 R $\$$, and $200,000 \mathrm{R} \$$ and finally $1,000,000 \mathrm{R} \$$, resulting in a huge increase in the amount of funds available to Banco Palmas for microcredit purposes. However, in accordance with Banco do Brasil's operational policies, microcredit loans had to be issued in $\mathrm{R} \$$. Plus, Banco do Brasil charges Banco Palmas a monthly interest rate of $2 \%$ which is transferred to the microcredit loans. Although other aspects of Banco Palmas' lending methodology remained unchanged, these two specific requirements represented a significant shift from its original principles and philosophy of no-interest loans and the use of a social currency. The new interest rates follow the following rules: they vary between 1.5 (for women who receive Bolsa Familia benefit from government) to $2.5 \%$ if the amount requested is less than $\mathrm{R} \$ 2,500 \mathrm{R} \$$. Beyond this limit up to 15,000 , for formal business, the interest rate ranges from $2.5 \%$ to $3.5 \%$.

Since 2010, Instituto Palmas has brought other options to Conjunto Palmeiras households, establishing a partnership with Caixa Econômica, another large public Brazilian bank. In this case, the credit evaluation system is more bureaucratic than credit obtained from Banco do Brasil and conditions are based on SPC (consumer protection system), which is a formal credit system used by all banks. Nowadays, however, the main access to resources is available through the partnership that Instituto Palmas developed with BNDES (a public development bank). Through this partnership, Instituto Palmas had access to an amount of 3,000,000 R $\$$.

Besides the partnerships with banks, Instituto Palmas also established a partnership with the Brazilian government, specifically with SENAES (national secretariat for economic solidarity under the aegis of the Ministry of Labour and Employment of Brazil), in order to facilitate development of the network of community banks in Brazil. SENAES objective is to disseminate the methodology of Banco Palmas to other regions of Brazil, and made it possible by providing resources to Instituto Palmas.

Partnerships with private companies were also arranged so that Instituto Palmas could offer services of life micro-insurance to Conjunto Palmeiras inhabitants. The Zurich company assumed the responsibility of providing resources to families in case of disaster and Camed company acts as a broker. Banco Palmas is the intermediary. Since 2011, there are two types of microinsurance. The first one is the Palmas Microinsurance which costs $35 \mathrm{R} \$$ per year and gives the right to insurance payments of 3,000 $\mathrm{R} \$$ in case of the insurer death. By contracting for that insurance, the insured takes part in a national monthly lottery drawing with a prize of 5,000 $\mathrm{R} \$$. The second type is the Palmas Bolsa Familia Microinsurance, which targets women who receive the Bolsa Familia benefit from the Brazilian Government. The cost is $10.00 \mathrm{R} \$$ per year and provides insurance benefits of $1,000 \mathrm{R} \$$ in case of death ${ }^{1}$.

Besides the aforementioned, other partnerships with local governments and NGOs have been developed since Banco Palmas was created, most of the time to leverage resources and disseminate its methodology.

\section{Creating new community banks}

In order to create a community bank, the project must first be backed by an existing organization, such as a local foundation or association or an organization from the public or private sectors. A local foundation or association contacts Instituto Palmas and requests further information on the creation of a community bank. This process is defined as a bottom-up approach, since the 
THE EXPANSION OF COMMUNITY BANKS IN BRAZIL: DISCOVERING PALMAS’ METHODOLOGY Marlei Pozzebon, Tania Pereira Christopoulos, Jahan Ara Peeraly, Fabio Prado Saldanha

interest in creation of a bank comes from the community. It is similar to the process which led to the creation of Banco Palmas through the direct efforts of the community and ASMOCOMP.

The public sector, represented by local or federal governments, can also create community banks by having recourse to Instituto Palmas' services and knowledge. Such public sector initiatives have also taken place outside Brazil, as when Instituto Palmas was contracted by the Government of Venezuela to train a team of government officials in launching Venezuelan community banks. This case exemplifies a top-down approach, as the initiative came from the government and not from the Venezuelan local communities.

Private sector initiatives entail private companies which are interested in enhancing development in territories where they are located or wish to locate. A successful example of such a private sector initiative includes the involvement of an electricity company in the creation of a community bank in the state of Rio de Janeiro. The company had to regularly cut electricity supply to local residents due to their inability to pay their electricity bills. The company realized that providing the locals with access to financial services and loans with attractive interest rates would not only resolve the issue of unpaid electricity bills but could also lead to local economic development.

Instituto Palmas concentrates its efforts on excluded communities where the impact is the most meaningful. Asier Ansonera, microcredit director at Instituto Palmas, is adamant that community banks can only thrive in territories where inhabitants are committed to, and embrace the project. He emphasizes:

"Before a bank can be implemented or started anywhere, the community has to be interested... and the community has to be responsible for the management of the community bank.... Because ultimately, it's up to the community to decide whether they want to have a bank or not."

Communities must not only be committed to the development of the banks, they must ensure the sustainability of their banks through creation of partnerships without the intervention of Instituto Palmas. They must show autonomy which is considered as a prerequisite for success.

\section{A diversity of challenges and barriers}

The expansion of community banks across Brazil has revealed a diverse set of challenges and barriers to Instituto Palmas.

First, community banks can operate in Brazil under different legal configurations. There is no unifying legal configuration to encompass their mission, activities and products. As a consequence, a community bank can operate in different forms, such as an NGO, a local association, a local union or an OSCIP (civil society organization for public interests). None of these aforementioned forms are adequately suited to the proper functioning of community banks.

Secondly, public bureaucracy at the federal or local government level has become the Achilles' heel of community banks. With time and experience, Instituto Palmas has learned how to deal with public bureaucracy. Nevertheless, public bureaucracy remains a barrier to the development of community banks since public policies and procedures vary among the different regions, and community banks seldom have the organisational and administrative structures to handle these regional differences.

Thirdly, the most common barrier to creating a community bank is insufficient funds. Very often, the creation of a community bank can be stalled because the initial estimates for capital fell short of the real level of funds required by the project.

Fourthly, in some cases the community itself can also be an obstacle to the creation of a bank. Thus, to avoid community resistance the first task performed by Instituto Palmas is explaining to the residents what a community bank is, its mission, activities and objectives. The longer it takes the residents to understand the basic concepts of a community bank, the longer it takes Instituto Palmas 
THE EXPANSION OF COMMUNITY BANKS IN BRAZIL: DISCOVERING PALMAS’ METHODOLOGY Marlei Pozzebon, Tania Pereira Christopoulos, Jahan Ara Peeraly, Fabio Prado Saldanha

to decide on the launching of social currency and the products of banking correspondence to be offered.

Once the above challenges and barriers are overcome, the institute must undertake the following steps in setting up a community bank. First, it sends technicians to the community in order to establish contact with the residents and explain the structure, purposes and functioning of the bank. Second, the institute tracks local associations which may be interested in managing the bank. Third, Instituto Palmas instructors will seek out, recruit, hire and train local individuals who are comfortable with the methodological procedures which are imperative to the daily operations of the bank. Asier describes the arduous nature of the process:

“... to find the right people to manage the bank... who will be the bank manager, the cashier, the loan agent, the loan officer... Training them to make sure that they will work well; this is the most difficult thing. Because it is work that is very detail oriented, and with which we have to be very careful, and we work in communities where people have a very limited education."

\title{
Ingredients for success
}

Instituto Palmas maintains that main ingredient for the success of community banks is not financial services or microcredit since these are not sufficient for promoting social inclusion. Cohesion among community members is the indispensable ingredient for success. Asier explains:

\begin{abstract}
"The more structure a community has, in terms of social contact, basically how people relate to each other within the community, the higher the chances are that a community bank will succeed... And this challenge is huge, because the bank not only needs to manage and deal with financial inclusion, but also deal with extreme social exclusion where people do not even know about their own territory."
\end{abstract}

Another important element for success is Instituto Palmas' "territorial approach" based on creating financial and non-financial tools designed to respond to the different needs, realities and expectations of different territories. The ultimate goal is to stimulate empowerment of each territory and encourage eventual self-management capacity, independent of the institute, and autonomy from the local government. In some cases, Instituto Palmas has to monitor and support the banks for a few years, in order to consolidate the latter's management and to encourage them to independently create partnerships with other supporting organizations.

The presence or absence of local factories, businesses and producers also helps determine the impact and success of community banks. In communities where local associations are active, opening a community bank leverages the existing local economic dynamic and generates wealth and growth. Asier summarizes the conditions that allow a community bank to blossom:

"So, which factors affect that local ecosystem? I would say, local social fabrics including local associations that have credibility with the community. Educational capacity in the location, support from the local government, and a clear idea of what runs the economic life of the territory also helps."

\section{Palma Lab: appropriation and co-production of technologies}

One of the major developments which technology brought about was allowing community banks to act as banking correspondents on behalf of other major financial institutions in Brazil. Banking correspondence involves arrangements between traditional banks and community banks whereby the latter agree to act as an outlet for the former's financial services. Through the use of point of sale devices or basic personal computers which act as terminals used for financial transactions, clients can pay bills, open bank accounts, deposit or transfer money, access credit, bank account balance and statement and withdraw government benefits from the community banks. As a 
THE EXPANSION OF COMMUNITY BANKS IN BRAZIL: DISCOVERING PALMAS’ METHODOLOGY Marlei Pozzebon, Tania Pereira Christopoulos, Jahan Ara Peeraly, Fabio Prado Saldanha

banking correspondent, the community banks then have to deal in both $\mathrm{R} \$$ (issued on behalf of traditional banks) and social currencies.

Thus, people in excluded locations were able to open bank accounts, pay bills, deposit and transfer money with traditional banks through community banks which acted as banking correspondents. However, Asier points out that,

"Banking correspondence has not evolved much since it was first created. It was huge, it was very helpful, and it continues to be very helpful in many communities, because these communities now have access to basic banking services, and because the technology provides them with those services. But banking correspondence did not continue to develop into the kind of products that can further develop those communities. So, banking correspondence continues to provide very basic services, and now, these communities - whether excluded or recently included - they have a demand for many more services, more sophisticated, involving larger loan amounts, more flexible conditions, etc."

Instituto Palmas knows that this gap can be only filled by adopting and using new technologies. The challenge is to develop or acquire technologies which have a reasonable cost-benefit ratio. Thus, the institute is engaged in developing adapted technological tools in order to provide suitable products to the excluded communities. Asier notes that technology can:

"...have big impacts on how Instituto Palmas deals with education barriers that are in many of these communities; where they do not have a lot of time for basic education, to use advanced types of software. But they know how to operate cell phones, they know how to operate basic types of software, because everybody has them."

To that end, Instituto Palmas is presently developing, in partnership with the Indian organisation Mahiti Infotech, a free software system for information management called OurBank designed specifically for microcredit institutions. The software will improve the life of households in Conjunto Palmeiras itself and will also be crucial to the network of community banks in several ways. Different solutions for improving internal administration, relationships with clients, and financial products are available through OurBank. The first is the Palmap - software to enable Instituto Palmas to map the local production through a digital solution. This is a major step forward compared to the current manual system for mapping local production. The second OurBank improvement in Banco Palmas technology is a solution that enables Instituto Palmas and merchants to create a digital questionnaire and apply it digitally within the community. This solution is more cost-effective than earlier manual questionnaires applied by Instituto Palmas to conduct research in Conjunto Palmeiras. The third OurBank technology will make possible for Banco Palmas to send SMS to the community, useful when it is necessary to inform someone that his/her loan is overdue.

Regarding the contribution to the network of community banks, for the time being, all existing softwares operate online by exchanging information between branches and requires an internet connection. OurBank, on the other hand, will not require the community bank to have access to the internet.

For Instituto Palmas, creating banking products and delivering them to communities are intrinsically linked to technology, since, as per Asier:

"... technology is going to give us the ability to make the entire process more flexible, more user-friendly, more efficient, more adapted and, cheaper, in general. So, if we are able to use technology in the whole process of designing and implementing, executing, monitoring - any product, service or strategy that we use - we are going to have much bigger impact, it is going to be easier to manage and to replicate the model of community banks." 
THE EXPANSION OF COMMUNITY BANKS IN BRAZIL: DISCOVERING PALMAS’ METHODOLOGY Marlei Pozzebon, Tania Pereira Christopoulos, Jahan Ara Peeraly, Fabio Prado Saldanha

It is not just the OurBank platform that has to be user-friendly, but also the procedures to create new products or to modulate the system without creating difficulties in the process. The environment where community banks are located may vary or may change quite rapidly. It therefore becomes imperative that the technology is quickly adaptable to new conditions, needs and regulations. The platform must be adapted to incorporate those changes while at the same time performing efficiently on a daily basis.

For Instituto Palmas, the cost efficient impact is as important as diminishing the geographic barriers between the excluded or recently included communities.

"[communities from all corners of Brazil will] participate in the process of delivering or creating products, through crowd-funding or crowd-sourcing, and other things that we are going to be looking into. They will come up with new ideas and products, strategies which will support our actions to lobby for changes in public policies, in general"'(Asier)

Thus, by expanding the network through the OurBank software, the lobbying power of community banks for influencing changes in public policies in their favour will also increase. The huge impact that the institute desires to obtain is to leap over this barrier, and create a legal framework for community banks, as mentioned before. Such positive externality would be brought by the use of new technologies.

The OurBank platform software is, therefore, the first of its kind. Both Instituto Palmas and Mahiti Infotech are presently working on a plan to create a research and innovation laboratory, where ideas and products can be developed to help the network of community banks expand and function more efficiently. As part of a bigger project called Palmas Lab, OurBank improvements go beyond delivering products to hone in on another objective: training local inhabitants to be capable of developing technological solutions in terms of existent community needs. Many other partners are involved to make the project possible. BNDES and Halloran Philanthropies provide financial support. SENAES provides institutional support, and Columbia University is a technical partner.

\section{Projeto Ellas - from training to citizenship}

In 2010, after having identified a huge demand for credit from women in Conjunto Palmeiras, Banco Palmas launched a specific credit line for them. Credit was conditional on being a woman from the community and receiving a benefit from the Brazilian government (Bolsa Família). The last condition was essential since it evinced that the woman did not work and needed an extra resource for living.

In 2011, Banco Palmas launched Projeto Ellas that would provide training and citizenship awareness to the women who received the above mentioned credit line. The fundamental assumption of that project is that "nobody overcomes poverty alone and without self-will". The credit is available for women who wish to invest in an existing business or to create a new one. For those who have never engaged in professional activity before, Banco Palmas offers training and seed money of $50 \mathrm{R} \$$. Women who have already developed a productive activity receive a credit amount ranging from 150 to 800 hundred $R \$$ and could evolve to $15 \mathrm{R} \$$ thousand, as they make the respective repayments ${ }^{8}$ (All these women may also acquire a special microinsurance, designed specifically for them.)

Each woman who takes the credit is accompanied by a community agent, whose responsibility is to provide financial education and social support and to organize them for training. Hence, those women are organized in groups by activity sector, such as cleaning material, culinary and clothing. After grouping, they are trained and can opt for starting a new business or entering the labor market.

\footnotetext{
${ }^{8}$ Instituto Palmas, 2013. http://www.institutobancopalmas.org/wp-content/uploads/carta_ministra_tereza_campello.pdf.
} 
THE EXPANSION OF COMMUNITY BANKS IN BRAZIL: DISCOVERING PALMAS' METHODOLOGY Marlei Pozzebon, Tania Pereira Christopoulos, Jahan Ara Peeraly, Fabio Prado Saldanha

Another instrument used to stimulate the group of women engaged in Projeto Ellas is a solidarity fund. The objective is to help women buy products they need to run their own business. To this end, Banco Palmas makes large joint purchases, thereby bringing down the prices. After that, Banco Palmas fund lends money to the women so that they can make the purchase from suppliers. They can pay Banco Palmas back in six installments.

The group has a managing council (numbering 33 in 2012) made up of women who participate in the project. They make decisions about the most important issues for the group, including leisure activities, for example. Recently, they made sightseeing and a cultural tour to downtown Fortaleza, with the participation of a hundred and fifty women, many of whom had never been there before.

Besides the managing council, there are indicators to help monitor Projeto Ellas. These indicators track whether women have leisure time or take part in a training group and even the number of visits to doctors. Following the philosophy of not only providing the money but also valorizing the women in the community, Projeto Ellas brings together women in equal conditions, and makes participation easy for them, inside the community and in their own reality. By the end of its first year (March 2012), the project had already provided credit for 1,200 women and 1,300 had already participated in the training workshops.

\section{Conclusion: Whereto Palmas?}

As they drive into Conjunto Palmeiras, Joaquim realizes that his feeling of pride in the progress that the community has made in the last 28 years never abates. Today, Conjunto Palmeiras has shed its slum status and is an urbanized neighborhood in its own right. With increasing local economic development, trade and business dealings outside the community have increased, thereby making the social currency Palmas less viable. Furthermore, local production for local consumption is no longer the community's main source of revenue. In addition, they need to worry about how to manage the rapid replication of the community bank network to other regions. These are some of the issues which he wishes to discuss with Asier, his right-hand man, and all the other partners in their enterprise. As they reach the Banco Palmas head office, Joaquim warmly thanks Asier for the ride from the airport. He adds,

"Asier, please set up a meeting for tomorrow. We need to discuss with everyone concerned the challenges that we are now facing in managing this huge number of community banks located in regions with different levels of economic development. [...] Moreover, we need to discuss the role of the social currency for community development over time." 
THE EXPANSION OF COMMUNITY BANKS IN BRAZIL: DISCOVERING PALMAS' METHODOLOGY Marlei Pozzebon, Tania Pereira Christopoulos, Jahan Ara Peeraly, Fabio Prado Saldanha

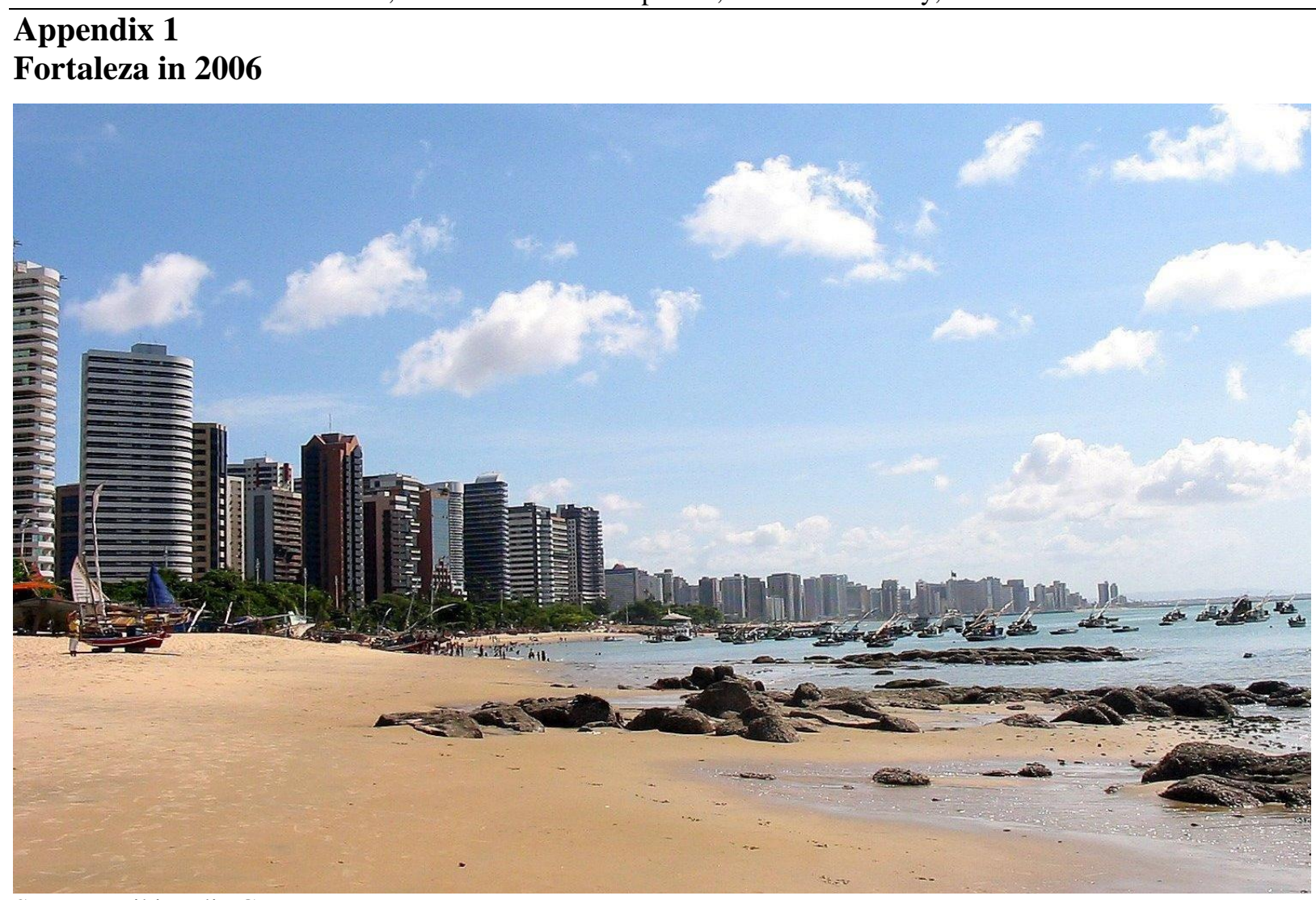

Source: Wikimedia Commons

\section{Appendix 2}

Fortaleza's coastal region in the 1970s
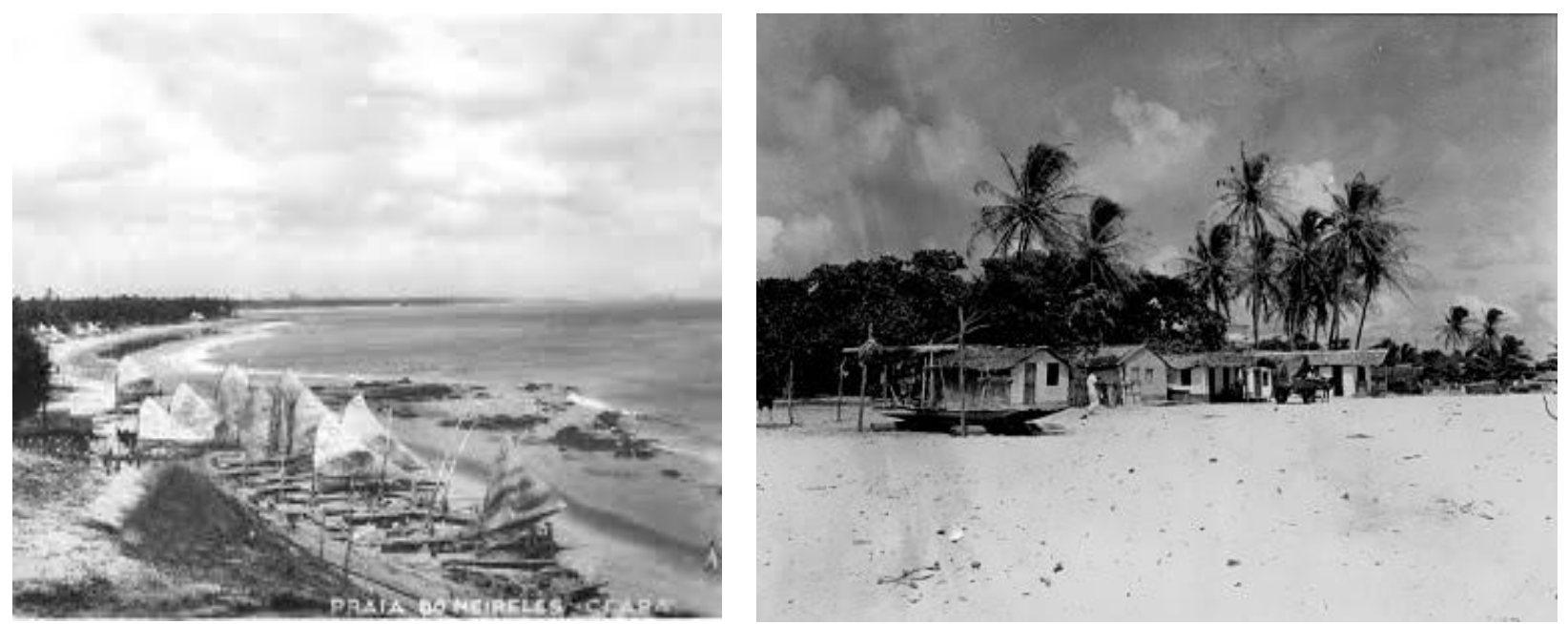

Source: Instituto Palmas 
THE EXPANSION OF COMMUNITY BANKS IN BRAZIL: DISCOVERING PALMAS' METHODOLOGY Marlei Pozzebon, Tania Pereira Christopoulos, Jahan Ara Peeraly, Fabio Prado Saldanha

\section{Appendix 3 \\ Creation of ASMOCONP through local community mobilization}
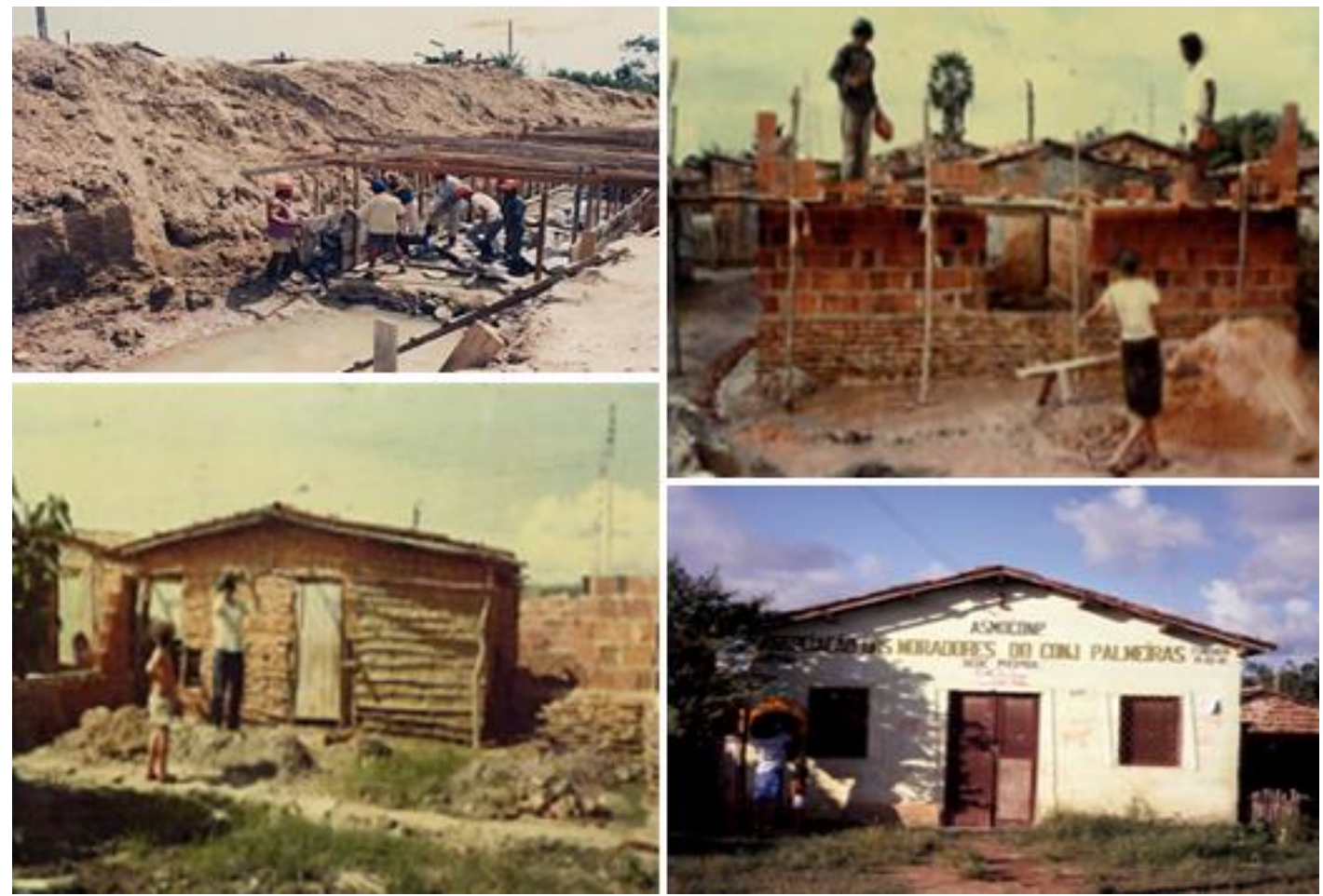

Source: Instituto Palmas

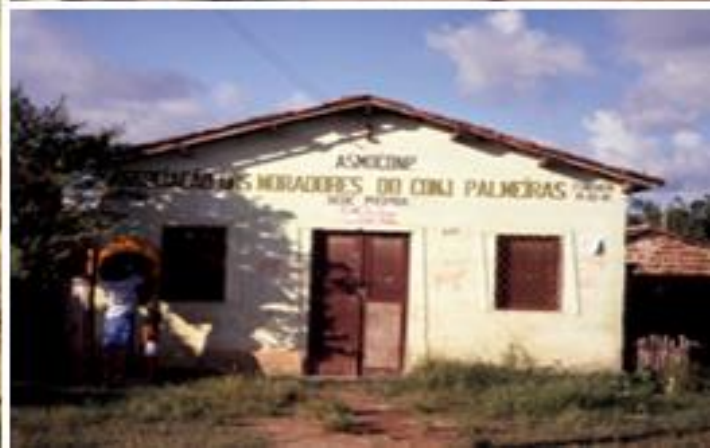

\section{Appendix 4}

Joaquim de Melo

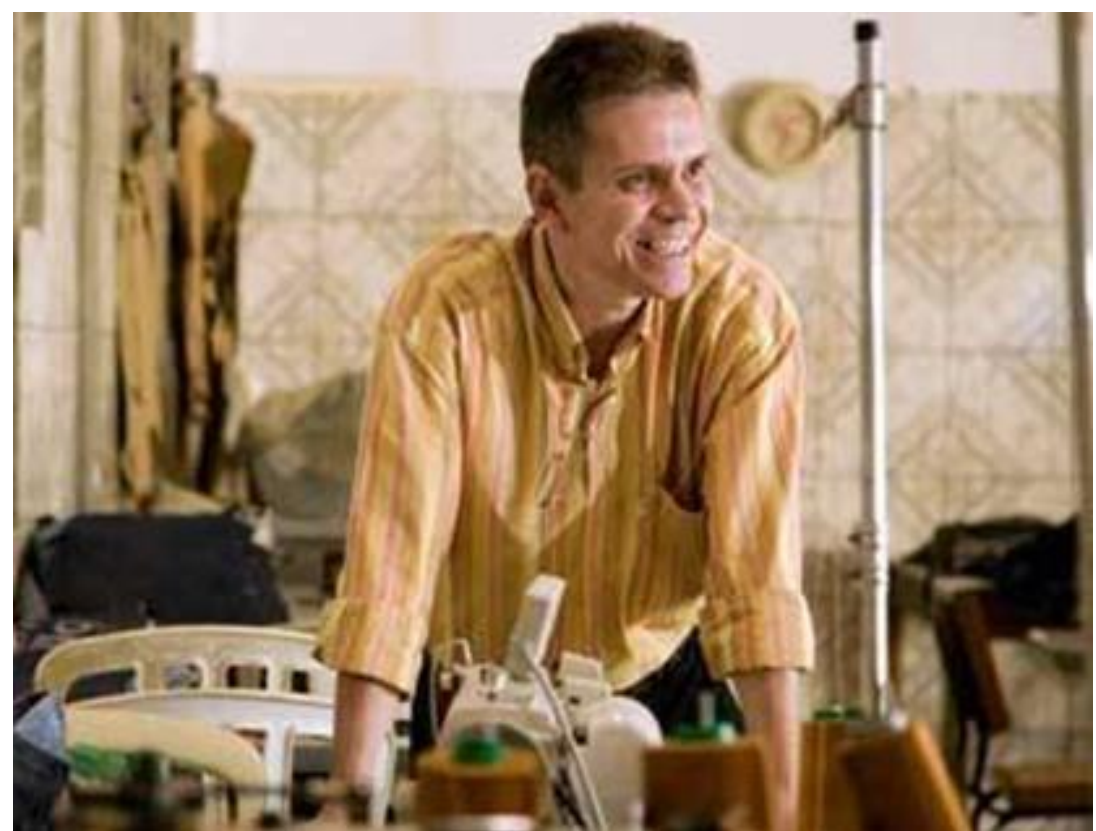

Source: Banco Palmas’ Facebook profile 
THE EXPANSION OF COMMUNITY BANKS IN BRAZIL: DISCOVERING PALMAS' METHODOLOGY Marlei Pozzebon, Tania Pereira Christopoulos, Jahan Ara Peeraly, Fabio Prado Saldanha
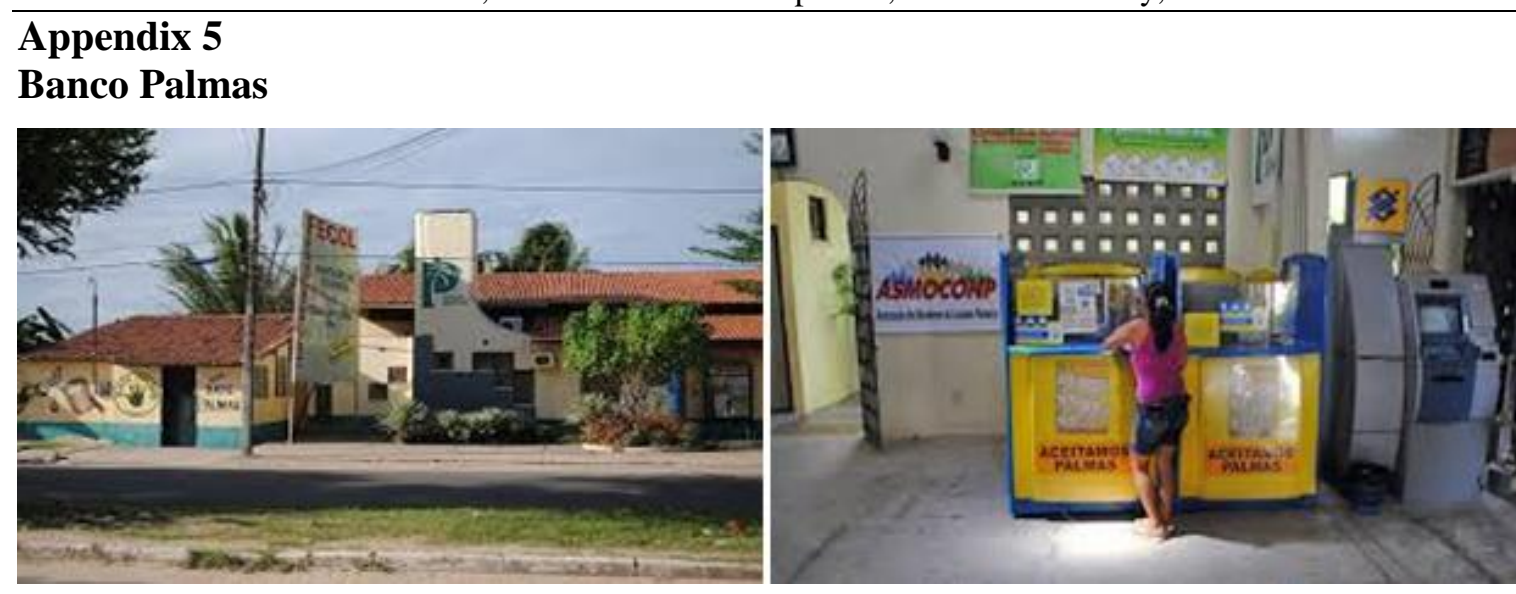

Source: Instituto Palmas

\section{Appendix 6:}

Palmas are issued on security paper

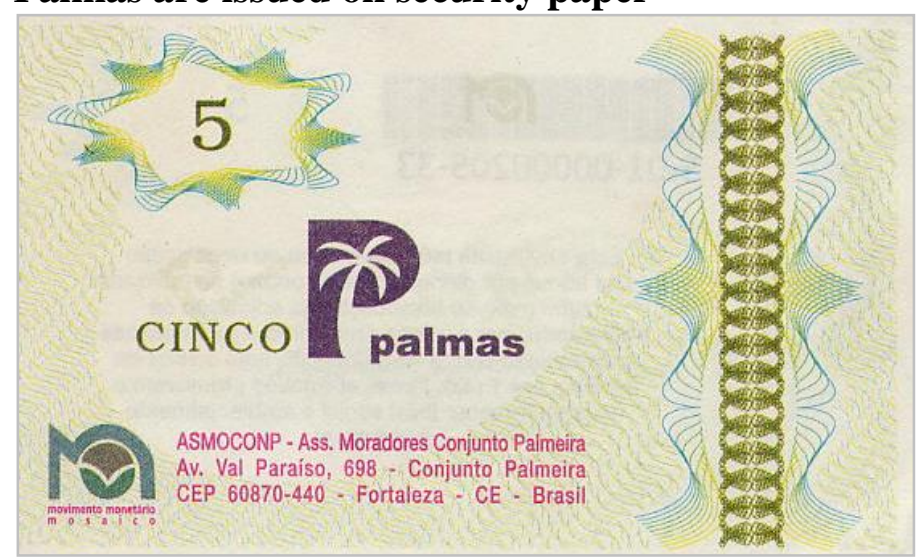

Source: Instituto Palmas

\section{Appendix 7 \\ The PalmaCard}
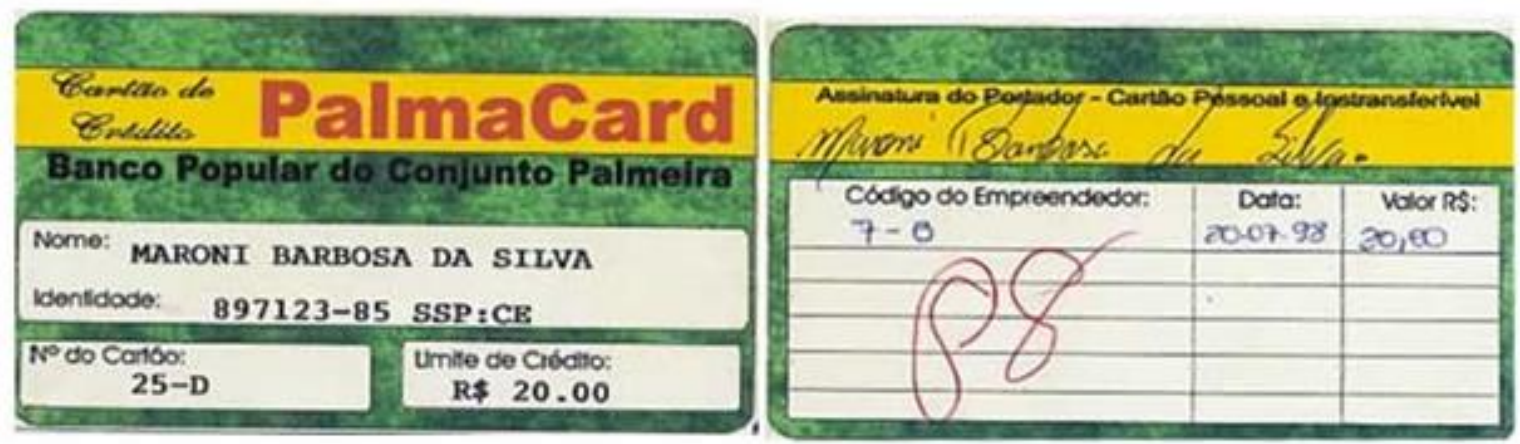

Source: Instituto Palmas) 
THE EXPANSION OF COMMUNITY BANKS IN BRAZIL: DISCOVERING PALMAS’ METHODOLOGY Marlei Pozzebon, Tania Pereira Christopoulos, Jahan Ara Peeraly, Fabio Prado Saldanha

\section{Appendix 8}

Palminha, a social currency for children

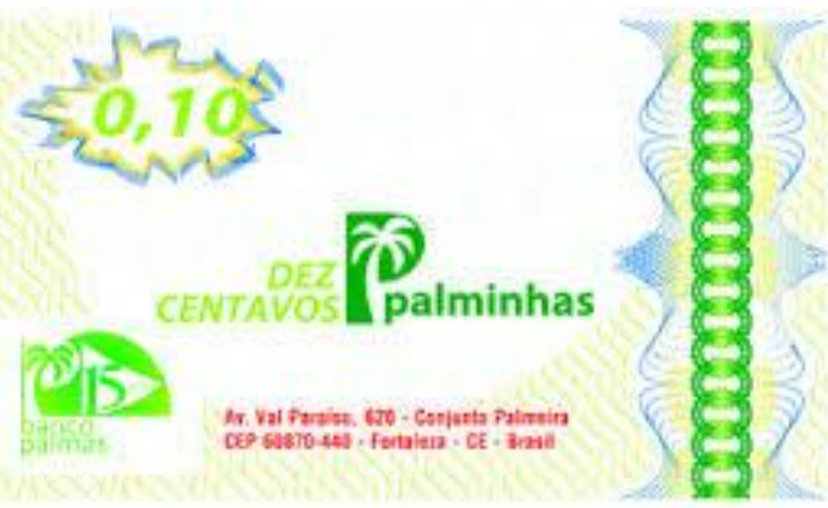

Source: Instituto Palmas

\section{Appendix 9:}

\section{Illustration of Local Consumption and Production Map and Card}

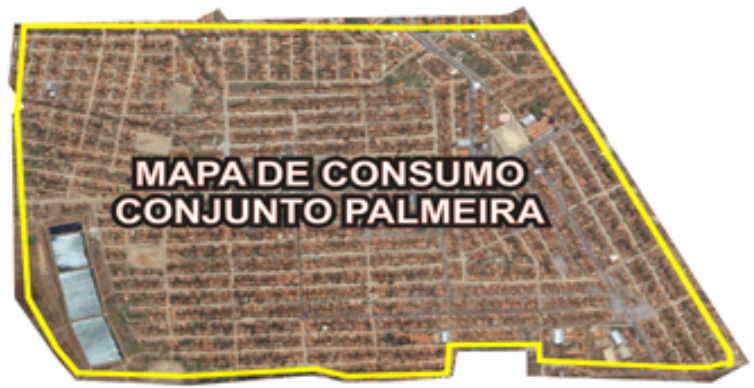

\begin{tabular}{|c|c|c|c|c|c|c|}
\hline product & unit & \begin{tabular}{|c|} 
monthly \\
quantity - \\
251 families \\
\end{tabular} & \begin{tabular}{|c|} 
monthly \\
quantity per \\
family \\
\end{tabular} & $\begin{array}{l}\text { total monthly } \\
\text { quantity - } \\
6.000 \text { families }\end{array}$ & unit cost ( $R \$)$ & $\begin{array}{c}\text { total monthly cost } \\
(\mathrm{R} \$)^{-}\end{array}$ \\
\hline beef & $\mathrm{kg}$ & 2.252 & 9 & 53.833 & 5,50 & $296.079,68$ \\
\hline chicken & $\mathrm{kg}$ & 3.124 & 12 & 74.677 & 3,20 & $238.967,33$ \\
\hline fruits & $\mathrm{kg}$ & 4.420 & 18 & 105.657 & 2,00 & $211.314,74$ \\
\hline cooking oil & I & 3.312 & 13 & 79.171 & 2,50 & $197.928,29$ \\
\hline rice & $\mathrm{kg}$ & 4.468 & 18 & 106.805 & 1,60 & $170.887,65$ \\
\hline bread & unit & 39.380 & 157 & 941.355 & 0,15 & $141.203,19$ \\
\hline fish & $\mathrm{kg}$ & 1.060 & 4 & 25.339 & 5,50 & $139.362,55$ \\
\hline beans & $\mathrm{kg}$ & 3.148 & 13 & 75.251 & 1,80 & $135.451,79$ \\
\hline sugar & $\mathrm{kg}$ & 3.664 & 15 & 87.586 & 1,50 & $131.378,49$ \\
\hline vegetables & $\mathrm{kg}$ & 3.320 & 13 & 79.363 & 1,50 & $119.043,82$ \\
\hline soda & 1 & 2.336 & 9 & 55.841 & 2,00 & $111.681,27$ \\
\hline coffee & $\mathrm{kg}$ & 1.972 & 8 & 47.139 & 2,00 & $94.278,88$ \\
\hline biscuits & pck & 1.716 & 7 & 41.020 & 1,85 & $75.886,85$ \\
\hline powder milk & I & 1.668 & 7 & 39.873 & 1,80 & $71.770,52$ \\
\hline milk & 1 & 2.264 & 9 & 54.120 & 1,30 & $70.355,38$ \\
\hline pasta & pck & 2.196 & 9 & 52.494 & 1,30 & $68.242,23$ \\
\hline eggs & unit & 17.340 & 69 & 414.502 & 0,15 & $62.175,30$ \\
\hline flour & $\mathrm{kg}$ & 1.784 & 7 & 42.645 & 1,00 & $42.645,42$ \\
\hline vinegar & bottle & 732 & 3 & 17.498 & 1,90 & $33.246,22$ \\
\hline corn flour & $\mathrm{kg}$ & 1.696 & 7 & 40.542 & 0,70 & $28.379,28$ \\
\hline maniocflour & $\mathrm{kg}$ & 636 & 3 & 15.203 & 1,80 & $27.365,74$ \\
\hline mayonnaise & bottle & 404 & 2 & 9.657 & 1,50 & $14.486,06$ \\
\hline salt & $\mathrm{kg}$ & 1.004 & 4 & 24.000 & 0,30 & $7.200,00$ \\
\hline molasses & unit & 512 & 2 & 12.239 & 0,50 & $6.119,52$ \\
\hline \multicolumn{6}{|r|}{ TOTAL } & $2.495 .450,20$ \\
\hline
\end{tabular}


THE EXPANSION OF COMMUNITY BANKS IN BRAZIL: DISCOVERING PALMAS' METHODOLOGY Marlei Pozzebon, Tania Pereira Christopoulos, Jahan Ara Peeraly, Fabio Prado Saldanha

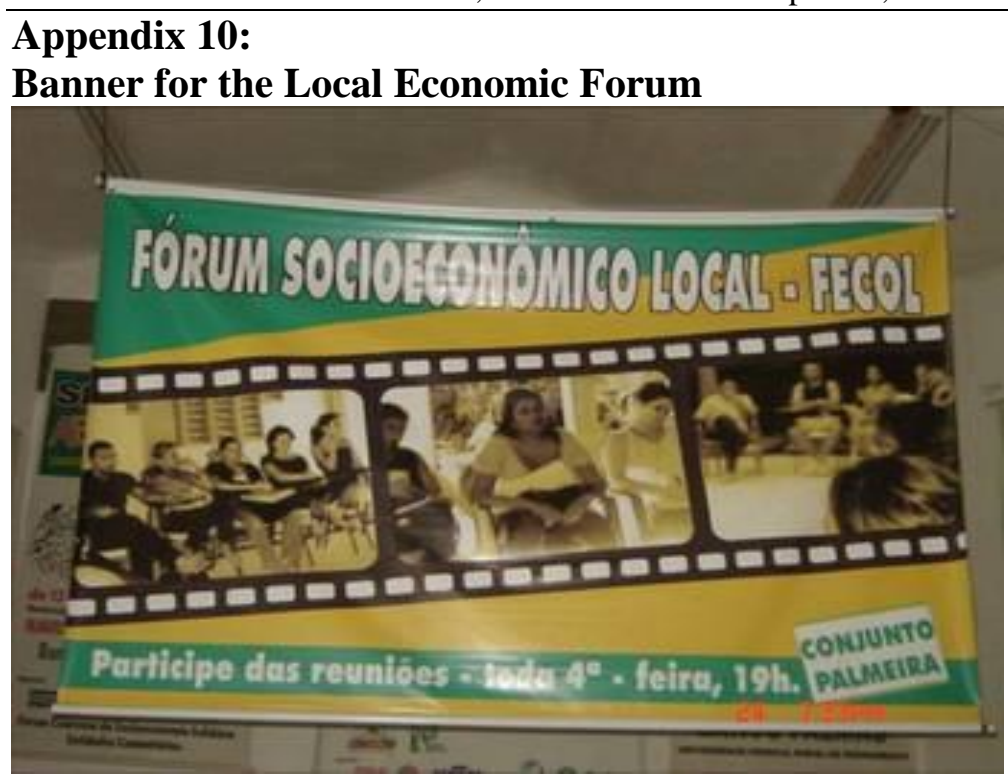

Source: Instituto Palmas

\section{Appendix 11}

Solidarity businesses founded by ASMOCONP
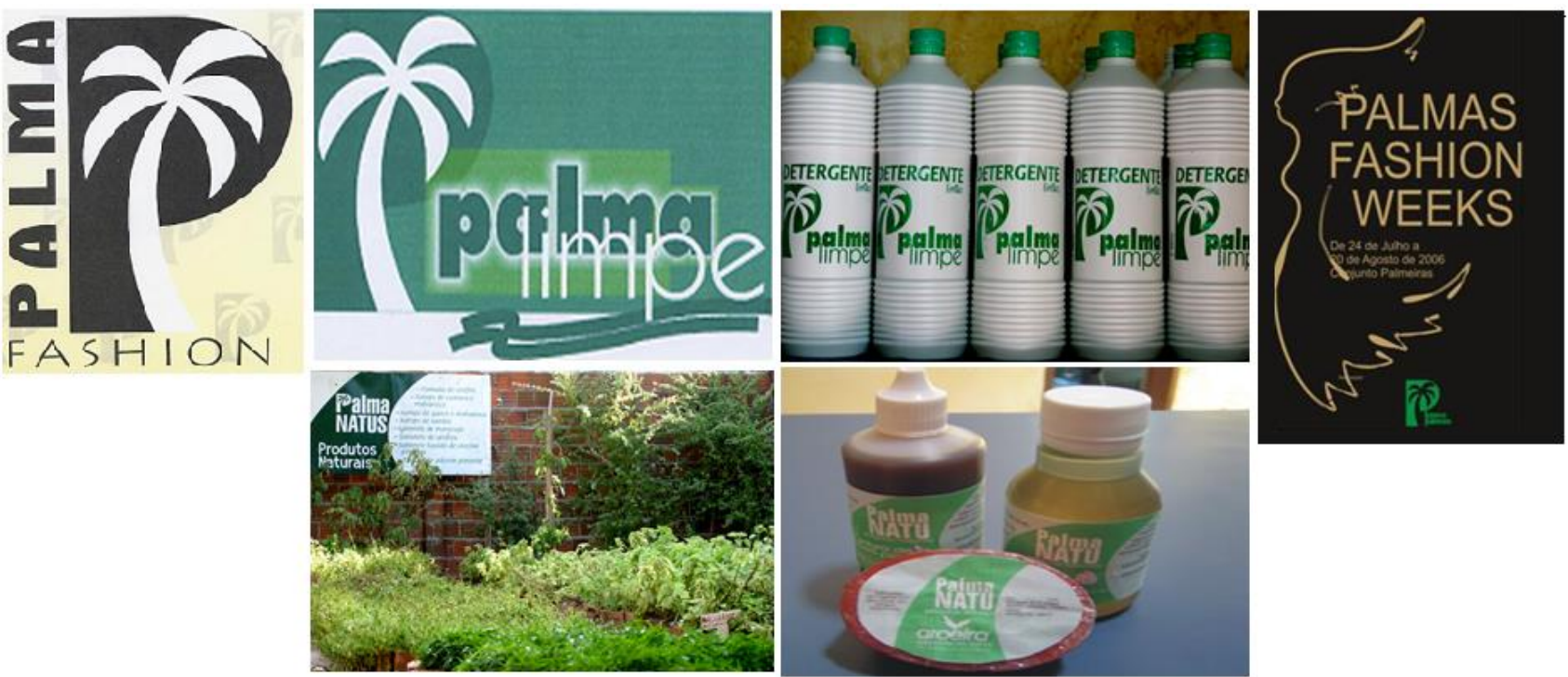

Source: Instituto Palmas 
THE EXPANSION OF COMMUNITY BANKS IN BRAZIL: DISCOVERING PALMAS' METHODOLOGY Marlei Pozzebon, Tania Pereira Christopoulos, Jahan Ara Peeraly, Fabio Prado Saldanha
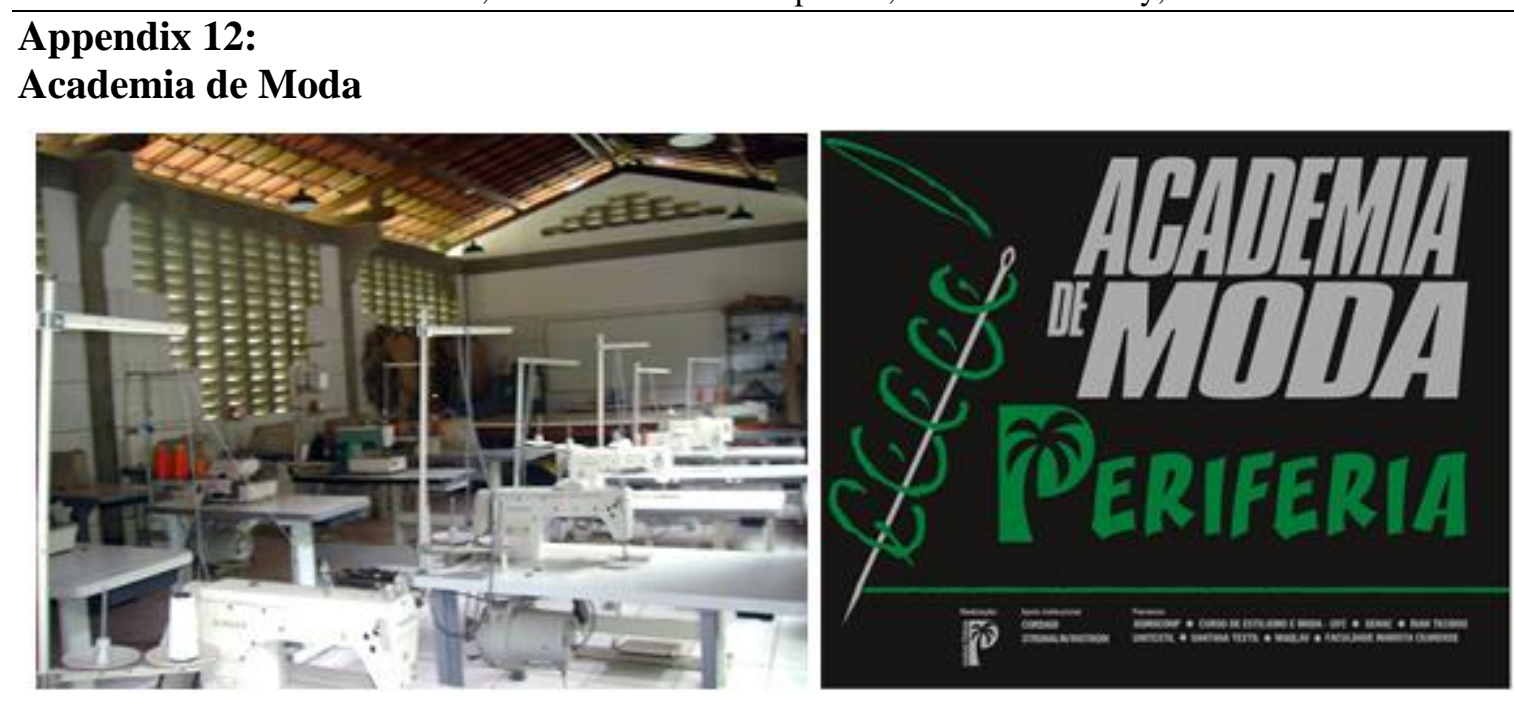

Source: Instituto Palmas

\section{Appendix 13}

The expansion of Palmas' community banks

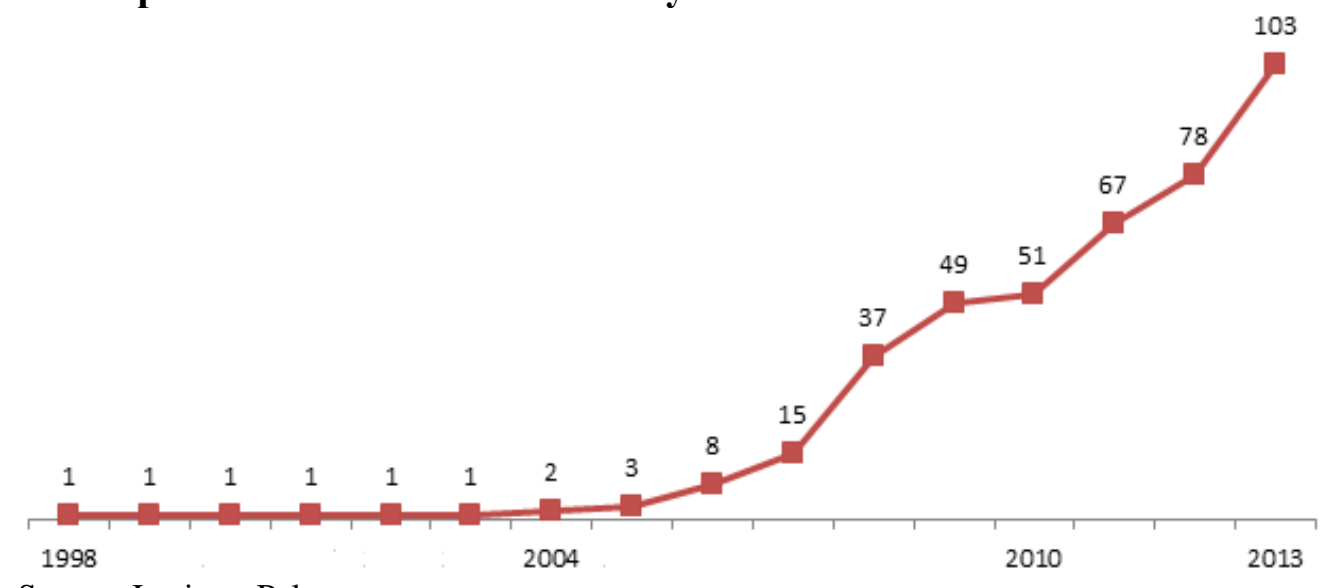

Source: Instituto Palmas 